\title{
Aromatase and Its Inhibitors: Significance for Breast Cancer Therapy
}

\author{
Evan R. Simpson* and Mitch DowsetT ${ }^{\dagger}$ \\ *Prince Henry's Institute of Medical Research, Monash Medical Centre, Clayton, \\ Victoria 3168, Australia; 'Department of Biochemistry, Royal Marsden Hospital, \\ London SW3 6JJ, United Kingdom
}

\begin{abstract}
Endocrine adjuvant therapy for breast cancer in recent years has focussed primarily on the use of tamoxifen to inhibit the action of estrogen in the breast. The use of aromatase inhibitors has found much less favor due to poor efficacy and unsustainable side effects. Now, however, the situation is changing rapidly with the introduction of the so-called phase III inhibitors, which display high affinity and specificity towards aromatase. These compounds have been tested in a number of clinical settings and, almost without exception, are proving to be more effective than tamoxifen. They are being approved as first-line therapy for elderly women with advanced disease. In the future, they may well be used not only to treat young, postmenopausal women with early-onset disease but also in the chemoprevention setting. However, since these compounds inhibit the catalytic activity of aromatase, in principle, they will inhibit estrogen biosynthesis in every tissue location of aromatase, leading to fears of bone loss and possibly loss of cognitive function in these younger women. The concept of tissue-specific inhibition of aromatase expression is made possible by the fact that, in postmenopausal women when the ovaries cease to produce estrogen, estrogen functions primarily as a local paracrine and intracrine factor. Furthermore, due to the unique organization of tissue-specific promoters, regulation in each tissue site of expression is controlled by a unique set of regulatory factors. These factors are potential targets for the design of selective aromatase modulators, which could selectively inhibit aromatase expression in breast with the same efficacy as the phase III inhibitors of activity but leave expression in other local sites such as bone and brain untouched.
\end{abstract}

\section{Aromatase and Its Gene}

Estrogen biosynthesis is catalyzed by a microsomal member of the cytochrome P450 superfamily, namely, aromatase cytochrome P450 (P450arom, the product of the CYP19 gene). The P450 gene superfamily is a very large one, containing (as of 1996) over 480 members in 74 families, of which cytochrome P450arom is the sole member of family 19 (Nelson et al., 1996). This heme protein is responsible for binding of the $\mathrm{C}_{19}$ androgenic steroid substrate and catalyzing the series of reactions leading to formation of the phenolic A ring characteristic of estrogens. 
The human CYP19 gene was cloned some years ago (Means et al., 1989; Harada et al., 1990; Toda et al., 1990), when it was shown that coding region spans nine exons, beginning with exon II. Upstream of exon II are a number of alternative first exons that are spliced into the $5^{\prime}$-untranslated region of the transcript in a tissue-specific fashion (Figure 1). For example, placental transcripts contain at their $5^{\prime}$-end a distal exon, I.1. This is because placental expression is driven by a powerful distal promoter upstream of exon I.1 (Means et al., 1991). Examination of Human Genome Project data reveals that exon I.1 is $89 \mathrm{~kb}$ upstream of exon II (Sebastian and Bulun, 2001). On the other hand, transcripts in ovary and testes contain at their $5^{\prime}$-end sequence that is immediately upstream of the translational start site. This is because expression of the gene in the gonads utilizes a proximal promoter, promoter II. By contrast, transcripts in cells of mesenchymal origin (e.g., adipose stromal cells, osteoblasts) contain yet another distal exon (I.4) located $20 \mathrm{~kb}$ downstream of exon I.1 (Mahendroo et al., 1993). Adipose tissue transcripts also contain promoter II-specific exonic sequences that are undetectable in bone (Shozu and Simpson, 1998).

Splicing of these untranslated exons to form the mature transcript occurs at a common 3 '-splice junction upstream of the translational start site. This means that although transcripts in different tissues have different $5^{\prime}$-termini, the coding region - and thus the protein expressed in these various tissue sites - is always the same. However, the promoter regions upstream of each of the several untranslated first exons have different cohorts of response elements, so regulation of aromatase expression in each tissue differs. Thus, the gonadal promoter (II) binds the transcription factors cyclic AMP (cAMP) response binding protein (CREB) and steroidogenic factor 1 (SF1), so aromatase expression in gonads is regulated by cAMP and gonadotrophins. In adipose tissue, promoter II-mediated expression is stimulated by prostaglandin $\mathrm{E}_{2}$. On the other hand, promoter I.4 is regulated by class I cytokines such as interleukin (IL)-6, IL-11, and oncostatin M as well as by tumour necrosis factor alpha $(\mathrm{TNF} \alpha)$. Thus, the regulation of estrogen biosynthesis in each tissue site of expression is unique (reviewed in Simpson et al., 1997). This situation leads to a complex physiological situation that makes, for example, interpretation of circulating estrogen levels as a marker of aromatase activity in specific tissues or in response to specific stimuli very difficult.

\section{The Concept of Local Estrogen Biosynthesis}

In premenopausal women, the ovaries are the principal source of estrogen, which functions as a circulating hormone to act on distal target tissues. However, this is no longer the case in postmenopausal women, when the ovaries cease to produce estrogens, and in men. Under these circumstances, estradiol is no longer 

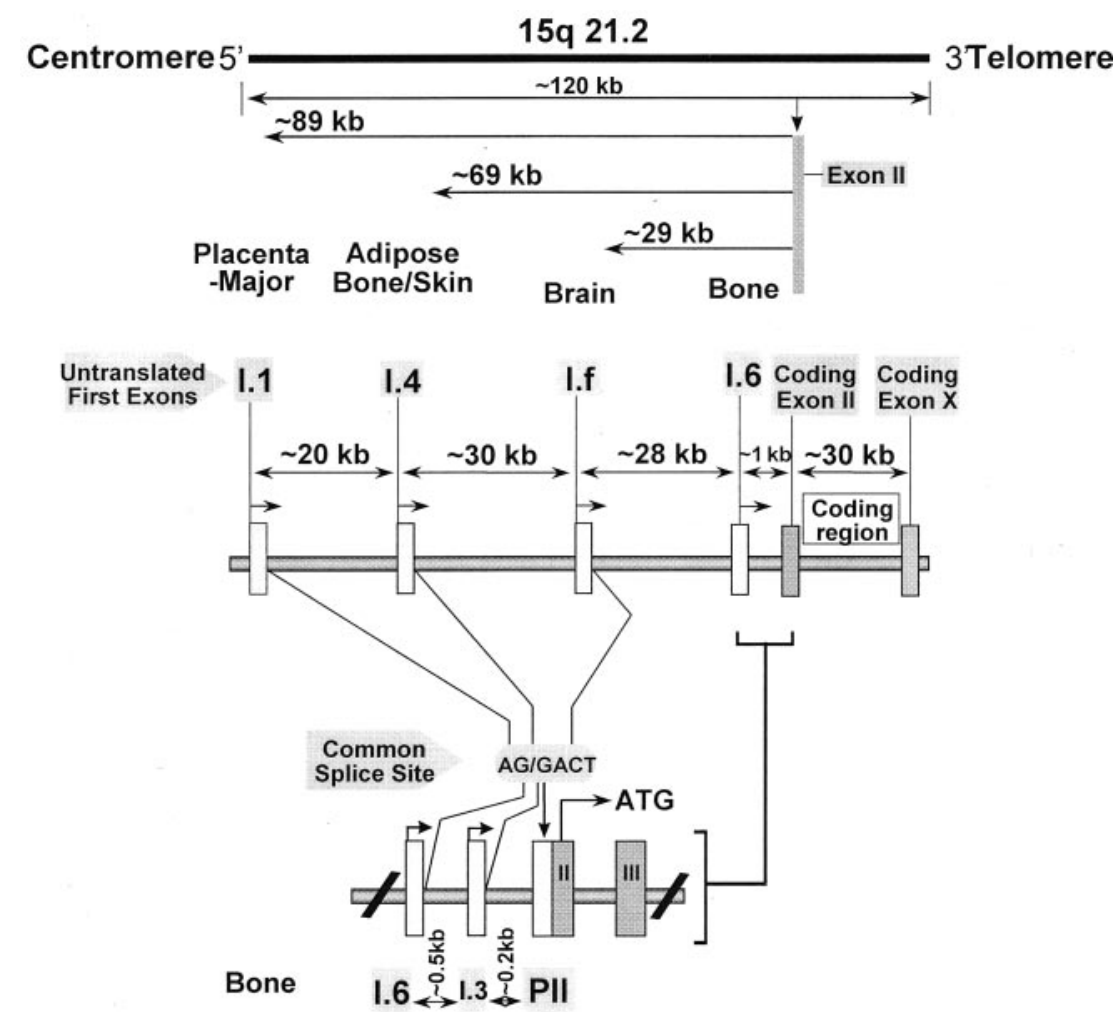

\section{Adiposel Breast Cancer

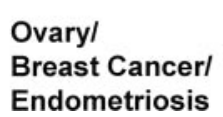

FIG. 1. Genomic organization of the human CYP19 gene. BLAST searches of various promoters and coding region revealed alignment to distinct locations in two overlapping BAC clones of chromosome 15q 21.2 region. The distance of each promoter with respect to the first coding exon (exon II) also was determined. The major placental promoter I.1 is the most distally located (approximately $89 \mathrm{~kb}$ ). Even though each tissue expresses a unique untranslated first exon $5^{\prime}$ untranslated region (UTR), by splicing into a highly promiscuous splice acceptor site (AG/A\ACT) of exon II, the coding region and the translated protein is identical in all tissue sites of expression. [Adapted with permission from Sebastian S, Bulun SE 2001 A highly complex organization of the regulatory region of the human CYP19 (aromatase) gene revealed by the human genome project. J Clin Endocrinol Metab 86:4600-4602. Copyright The Endocrine Society.]

solely an endocrine factor. Instead, it is produced in a number of extragonadal sites where it acts locally, including the mesenchymal cells of adipose tissue, osteoblasts and chondrocytes of bone, the vascular endothelium and aortic 
smooth muscle cells, and numerous sites in the brain. Thus, circulating levels of estrogens in postmenopausal women and in men are not the sole drivers of estrogen action: they may be predominantly reactive rather than proactive. This is because circulating estrogen in this situation originates in extragonadal sites, where it acts locally. If it escapes local metabolism, it enters the circulation. Therefore, circulating levels in large part reflect, rather than direct, estrogen action in postmenopausal women and in men.

Extragonadal sites of estrogen biosynthesis possess several fundamental features that differ from those of the ovaries. First, the estrogen synthesized within these compartments acts predominantly at the local tissue level in a paracrine or intracrine fashion (Labrie et al., 1997,1998) (Figure 2). The total amount of estrogen synthesized by these extragonadal sites may be small but the local tissue concentrations achieved are probably high and exert biological influence locally. As a consequence, extragonadal estrogen biosynthesis plays an important but hitherto largely unrecognised physiological and pathophysiological role.

The power of local estrogen biosynthesis is illustrated in the case of postmenopausal breast cancer (Pasqualini et al., 1996). It has been determined that the concentration of estradiol present in breast tumours of postmenopausal women is at least 20-fold greater than that present in the plasma. With aromatase inhibitor therapy, intratumoural concentrations of estradiol and estrone drop precipitously, together with a corresponding loss of intratumoural aromatase activity, consistent with this activity being within the tumour and the surrounding

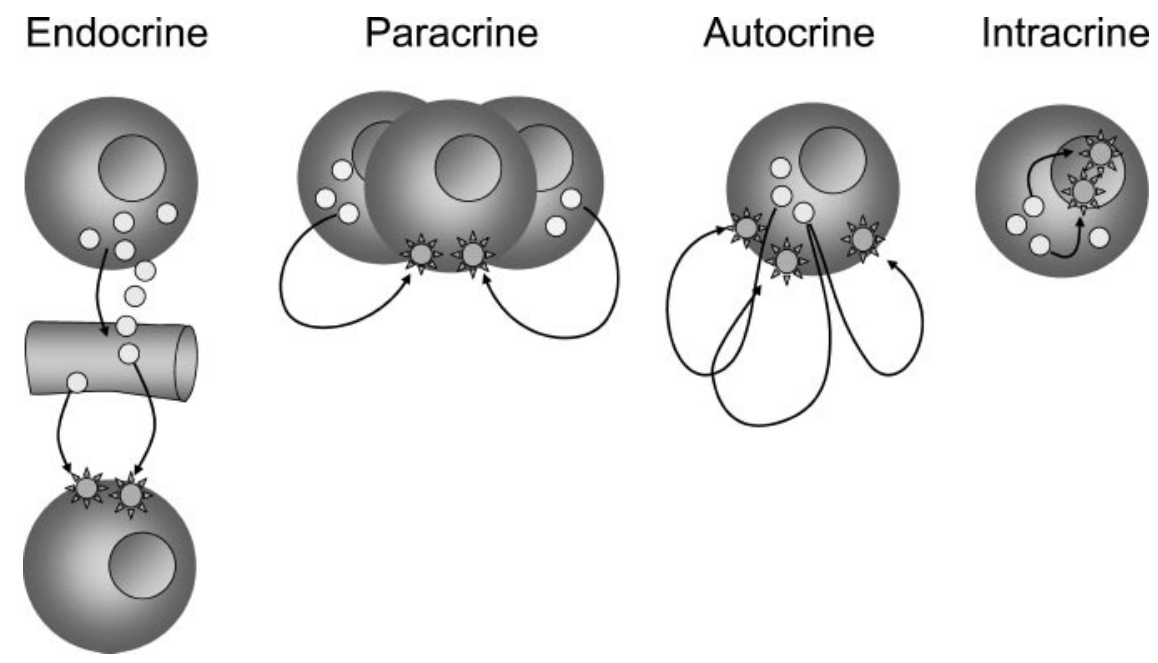

FIG. 2. Modes of action of endocrine, paracrine, autocrine, and intracrine factors. 
breast adipose tissue and being responsible for these high tissue concentrations (DeJong et al., 1997). Studies to assess directly the proportion of estrogen that is synthesized in breast tumours as opposed to reaching them from the blood are technically difficult but particularly instructive. The studies of Reed and colleagues as well as of Miller (Reed et al., 1989; Miller, 1999) indicate that the majority of breast tumours generate estrogen through the intratumoural route. However, this varies substantially between tumours, and overall, about half of the estrogen is produced locally within the tumour or surrounding tissue (Miller, 1999).

In bone, aromatase is expressed primarily in osteoblasts and chondrocytes (Sasano et al., 1997). Aromatase activity in cultured osteoblasts is comparable to that present in adipose stromal cells (Shozu and Simpson, 1998). Thus, it appears that in bone also, local aromatase expression is a major source of estrogen responsible for the maintenance of mineralization (although this is extremely difficult to prove due to sampling problems). Hence, for both breast tumours and bone, it is likely that circulating estrogen levels are only partly responsible for the relatively high endogenous tissue estrogen levels. The circulating levels reflect the sum of local formation in its various sites. This is a fundamental concept for interpreting relationships between circulating estrogen levels in postmenopausal women and estrogen insufficiency in specific tissues.

The second important point is that estrogen production in these extragonadal sites is dependent on an external source of $\mathrm{C}_{19}$ androgenic precursors, since these extragonadal tissues are incapable of converting cholesterol to the $\mathrm{C}_{19}$ steroids (Labrie et al., 1997a,1998). As a consequence, circulating levels of testosterone and androstenedione as well as dehydroepiandrosterone (DHEA) and DHEA sulfate (DHEAS) become extremely important in terms of providing adequate substrate for estrogen biosynthesis in these sites.

It should be pointed out that, in the postmenopausal woman, circulating testosterone and androstenedione levels are an order of magnitude greater than circulating estradiol and estrone levels. Differences in the levels of circulating androgens are likely to be important determinants for maintenance of local estrogen levels in extragonadal sites. Moreover, in men, circulating testosterone levels are an order of magnitude greater than those in postmenopausal women. In postmenopausal women, the ovaries secrete $25-35 \%$ of the circulating testosterone. The remainder is formed peripherally from androstenedione and DHEA produced in the ovaries and from androstenedione, DHEA, and DHEAS secreted by the adrenals. However, the secretion of these steroids and their plasma concentrations decrease markedly with advancing age (Labrie et al., 1997b).

In this context, it is appropriate to consider why osteoporosis is more common in women than in men and why it affects women at a younger age in terms of fracture incidence. We have suggested that uninterrupted sufficiency of circulating testosterone in men throughout life supports the local production of 
estradiol by aromatization of testosterone in estrogen-dependent tissues. This affords ongoing protection against the so-called estrogen deficiency diseases. This appears to be important in terms of protecting the bones of men against mineral loss and also may contribute to the maintenance of cognitive function and prevention of Alzheimer's disease (Simpson et al., 2000).

\section{Aromatase Inhibitors}

\section{A. BACKGROUND}

A large number of aromatase inhibitors have been developed and utilised in clinical studies over the last 20 years. The most successful are now being licensed mainly for breast cancer treatment (Buzdar and Howell, 2001; Goss and Strasser, 2001).

This development was prompted by the recognition that the cytochrome P450 inhibitor aminoglutethimide is an aromatase inhibitor (Thompson and Siiteri, 1974) and exerts its therapeutic effectiveness in postmenopausal women with advanced breast cancer via the inhibition of aromatase (Santen et al., 1978; Stuart-Harris et al., 1984). This recognition validated aromatase as a new target for treatment of breast cancer patients with hormone-dependent disease. The widespread acceptance that aminoglutethimide was anything but a perfect drug (e.g., significant clinical side effects, incomplete inhibition of aromatase, poor selectivity for aromatase leading to adrenal suppression) and the need for combination with glucocorticoid led to the development of numerous new drugs. These have generally been categorised as first-, second-, and third-generation inhibitors. Figure 3 categorises the structures of a selection of the most prominent. Aminoglutethimide is recognised as the dominant first-generation compound. The second generation showed improved potency but either metabolic or symptomatic side effects limited the dose at which these inhibitors could be used. Therefore, overall pharmacological efficacy of the compounds was no greater than that of aminoglutethimide itself (Boeddinghaus and Dowsett, 2001). In contrast, the third-generation compounds have been found to be highly specific and well tolerated such that they have been usable at dosages that effectively obliterate the activity of aromatase.

Many pathological states at least partly depend on continued estrogen stimulation and, thus, in principle, might be expected to be good targets for aromatase inhibition. However, most of these diseases (e.g., endometriosis, fibroids) are almost entirely limited to premenopausal women and are not subject to targeting with aromatase inhibitors alone. Thus, the clinical application of inhibitors has been confined almost entirely to the main estrogen-dependent disease in postmenopausal women (i.e., breast cancer). 


\section{Steroidal Inhibitors}

Formestane<smiles>CC12CC[C@H](O)C(O)=C1CCC1C2CCC2(C)C(O)CCC12</smiles>

\section{Exemestane}<smiles>C=C1CC2C(CCC3(C)C(=O)CCC23)C2(C)C=CC(=O)C=C12</smiles>

\section{Non-steroidal Inhibitors}

\section{Aminoglutethimide}<smiles>CCC1(c2ccc(N)cc2)CCC(=O)NC1=O</smiles>

\section{Fadrozole}<smiles>N#Cc1ccc(C2CCCc3cncn32)cc1</smiles>

Anastrozole

Vorozole

Letrozole<smiles>CC(C)(C)c1cc(Cn2cncn2)cc(C(C)(C)C#N)c1</smiles><smiles>Cn1nnc2ccc(Cn3cncn3)cc21</smiles><smiles>Cc1ccc(C(c2ccc(C#N)cc2)n2cncn2)cc1</smiles>

FIG. 3. Chemical structures of the most widely used aromatase inhibitors.

\section{B. STRUCTURE AND BASIS OF INHIBITION}

There are two main structural types of aromatase inhibitor: 1) steroidal, substrate analogs such as 4-hydroxyandrostenedione (formestane) and exemestane, and 2) nonsteroidal compounds that operate by virtue of their interaction with the cytochrome $\mathrm{P} 450$ heme prosthetic group of the aromatase enzyme (Kao et al., 1996). These are known as type I and type II inhibitors, respectively. While the steroidal group includes inhibitors that act in a competitive manner, those of 
greatest contemporary interest and clinical importance act as enzyme inactivators or suicide inhibitors (Brodie et al., 1981; Lonning, 2000). This activity requires that the enzyme itself converts the inhibitor to a chemically reactive intermediate that binds irreversibly and covalently to the protein structure of the enzymesubstrate binding site. Thus, the individual enzyme molecule is irreversibly inactivated and the inhibitor molecule is no longer available to interact with other enzyme molecules. These types of inhibitors have the potential for exquisite selectivity for the enzyme target and long-term effectiveness, since the recovery of enzyme activity depends on the re-synthesis of enzyme as well as on the pharmacokinetics of the drug. However, such steroidal structures also have the potential for hormonal activity. The potential advantage of long-term effectiveness is of little importance when the turnover of enzyme is rapid. It is notable that plasma estradiol levels rise relatively rapidly after cessation of orally administered formestane (Dowsett et al., 1987). This suggests that the aromatase enzyme is replenished in peripheral tissues within about 24 hours. Thus, this inactivation type of mechanism has yet to be demonstrated to be of significant clinical advantage (see below).

All type 2 inhibitors have a basic nitrogen atom that allows them to interact with the iron atom of the heme prosthetic group of the enzyme (Kao et al., 1996). Their specificity for inhibition of the aromatase enzyme (as opposed to the very large number of other cytochrome P450 enzymes) is determined by the other structural aspects of the drugs and the way that these allow a close fit to the substrate-binding site of aromatase. This results in high-affinity binding and limits the fit into the substrate-binding site of other enzymes. A full understanding of these molecular interactions has been restricted by the unavailability of a crystallized aromatase preparation for structural analysis of the inhibitor-enzyme interaction. Thus, computer-generated models have depended largely on the structural analogies that can be surmised between aromatase and the few cytochrome P450 enzymes whose structure has been determined (GrahamLorence et al., 1995; Graham-Lorence and Peterson, 1996). Use of such models has illustrated the much-better fit to the substrate-binding site of aromatase by the triazole compounds anastrozole, letrozole, and vorozole than by aminoglutethimide, with letrozole and vorozole apparently having a somewhat more complete space-filling effect (Kao et al., 1996).

The potency of these drugs generally has been assessed in vitro using human placental microsomal aromatase preparations. In this type of assay, fadrozole is one of the most potent drugs known, having an IC50 of $5 \mathrm{nM}$. However, its potency in vivo has been compromised by very rapid metabolism such that its vitro activity has not been matched in in vivo studies (Bhatnagar et al., 2001). Letrozole and anastrozole appear to have relatively similar IC50s to each other. But when these compounds have been tested on intact cells - including hamster ovarian tissue, human breast fibroblasts, and aromatase-transfected human breast 
cancer cells - a 10- to 30-fold difference in effectiveness has been found, with letrozole being the more potent. The explanation for the difference in the measurements made in intact cell and cell-free systems is not clear but may be related to uptake of the respective compounds. It might be expected that the intact cell systems would more accurately predict the likely effectiveness of these compounds in the in vivo setting.

\section{PRECLINICAL MODEL SYSTEMS}

Until recently, preclinical modelling of the use of aromatase inhibitors in rodents has been largely limited to premenopausal systems (i.e., those with intact ovarian function) because rodents appear to have little peripheral aromatase activity (in contrast to postmenopausal women, where these drugs have found their greatest application). In these models, the aromatase inhibitors generally have been shown to have good antitumour activity on carcinogen-induced mammary tumours (DeCoster et al., 1992; Brodie et al., 1983). However, the compounds also have had a marked effect on ovarian morphology, with the induction of multiple follicles due to the increase in gonadal stimulation from loss of estrogen feedback on the hypothalamic-pituitary axis (Shetty et al., 1997).

More recently, model systems have focused on the use of aromatasetransfected human MCF7 breast cancer cells in a xenograft model employing athymic nude mice (Lee et al., 1995; Lu et al., 1998). These are more representative of the situation in postmenopausal women and rely on intratumoural aromatase as their primary source of estrogen. Using such models, it has been possible to show the effectiveness of contemporary aromatase inhibitors and compare them with tamoxifen. In general, the inhibitors show greater efficacy than tamoxifen ( $\mathrm{Lu}$ et al., 1998). As always, the interpretation of these data depends on the comparative pharmacology of the compounds in the mouse and human and the degree to which the experimental tumour represents the range of biological characteristics of human breast cancer.

\section{PHARMACOLOGICAL EFFECTIVENESS}

\section{Peripheral Effects}

Two methodologies have been used to estimate the clinical pharmacological effectiveness of aromatase inhibitors. Most studies have accumulated data on the effects of the compounds on plasma estrogen levels. This methodology, however, suffers from a number of deficits. First, it cannot distinguish between effects on production and those that changes in clearance may have. However, a more important issue is the limited sensitivity of plasma estrogen assays: in effect, the maximum degree of suppression that can be shown of primary estrogens (estrone and estradiol) levels using the most sensitive immunoassays available is about 
$85 \%$. Many assays lack the sensitivity to show even this degree of efficacy. Thus, comparing results between different studies and approaches has little validity.

Of substantially greater value has been application of the more complicated methodology used to measure aromatase activity directly. This involves the injection of $\left[{ }^{3} \mathrm{H}\right]$-androstenedione and $\left[{ }^{14} \mathrm{C}\right]$-estrone before and during the treatment of women with the respective inhibitor (Jacobs et al., 1991). Collecting urine over a 72-hour period and establishing the $\left[{ }^{3} \mathrm{H}\right]:\left[{ }^{14} \mathrm{C}\right]$ ratio in the purified estrogen fractions allow calculation of the peripheral aromatase activity in the patient and the degree of inhibition exerted. An advantage of this methodology is that the inclusion of $\left[{ }^{14} \mathrm{C}\right]$-estrone provides an internal standard that permits better comparability of results between studies and over time.

Table I compares the degree of aromatase inhibition achieved among drugs of contemporary importance. This demonstrates that while aminoglutethimide and the second-generation inhibitors suppress aromatase by little more than $90 \%$ at their clinically used dosages, the new third-generation compounds approach complete ablation of aromatase activity. In a recent study, letrozole was found to inhibit by greater than $99 \%$ in all 12 patients (Geisler et al., 2001).

In contrast to the numerous effects of aminoglutethimide on adrenal steroidal function and other cytochrome P450-dependent processes (e.g., prostaglandin and thyroxine synthesis), the newer aromatase inhibitors essentially are completely specific at clinical dosages. Exemestane causes minor reduction in sex hormone-binding globulin (SHBG) levels, probably due to its androgenic nature. Letrozole has been noted to exert a statistically significant effect on corticotropin (ACTH)-stimulated adrenal function (Bajetta et al., 1999). However, these effects are unlikely to be of clinical significance.

TABLE I

Degree of Whole-body Aromatase Inhibition by Drugs Used in Breast Cancer Clinical Efficacy

\begin{tabular}{llcl}
\hline \multicolumn{1}{c}{ Drug } & \multicolumn{1}{c}{ Dose } & $\begin{array}{c}\text { Mean percentage } \\
\text { inhibition }\end{array}$ & \multicolumn{1}{c}{ Reference } \\
\hline $\begin{array}{l}\text { Aminoglutethimide } \\
(+ \text { hydrocortisone })\end{array}$ & $1000 \mathrm{mg}(+40 \mathrm{mg}) / \mathrm{d}$ & 90.6 & MacNeill et al., 1992 \\
Formestane & $250 \mathrm{mg} / 2 \mathrm{w}(\mathrm{im})$ & 84.8 & Jones et al., 1992 \\
Fadrozole & $2 \mathrm{mg} / \mathrm{d}$ & 82.4 & Lonning et al., 1991 \\
Vorozole & $1 \mathrm{mg} / \mathrm{d}$ & 93.0 & Van der Wall et al., 1993 \\
Letrozole & $2.5 \mathrm{mg} / \mathrm{d}$ & $>99.1$ & Geisler et al., 2001 \\
Anastrozole & $1 \mathrm{mg} / \mathrm{d}$ & 97.3 & Geisler et al., 2001 \\
Exemestane & $25 \mathrm{mg} / \mathrm{d}$ & 97.9 & Geisler et al., 1998 \\
\hline
\end{tabular}

[All analyses, other than Van der Wall et al. (1993) were conducted in the Dowsett laboratory.] 


\section{Premenopausal Women}

The observation that formation of multiple ovarian follicles occurs upon administration of aromatase inhibitors in animal model systems has discouraged the widespread investigation of these compounds in premenopausal women (Shetty et al., 1997). Studies with aminoglutethimide generally reveal that estrogen synthesis is largely unaffected by the aromatase inhibitor, although increases in gonadotrophins indicated a degree of compensated inhibition. Application of the more potent steroidal aromatase inhibitor, 4-hydroxyandrostenedione, even at the high dose of $500 \mathrm{mg} / \mathrm{week}$, had no significant impact on premenopausal estrogen levels. The only data from use of a potent nonsteroidal aromatase inhibitor in premenopausal women are from a single-dose study with vorozole. It showed some degree of suppression but duration with repeated doses is unknown. Thus, for the moment, application of aromatase inhibitors to treatment of premenopausal women with breast cancer is limited to their combined usage with gonadotropinreleasing hormone (GnRH) agonists such as goserelin. However, successful use of letrozole in ovulation induction in women with anovulatory infertility recently was reported (Mitwally and Casper, 2001). This is an area that merits substantial further investigation.

\section{Intratumoural Effects}

The observation that the aromatase enzyme is expressed in both normal and malignant breast has led to substantial investigation of the significance of enzyme source. In postmenopausal women, estrogen that is produced locally likely would cause at least as much stimulation of breast tissues as that by estrogen derived from the circulation. It is clear that aromatase inhibitors effectively suppress estrogen synthesis within the breast in almost all cases (DeJong et al., 1997; Miller, 1999). The degree of residual aromatase activity in tumours is very difficult to estimate, however.

Studies by Miller's group have indicated that a significant association may exist between the presence of intratumoural aromatase and the lesion's response to aromatase inhibitors (Miller and O'Neill, 1987). However, expanding these studies to the large scale required to establish any clinical utility of this observation has been limited by the relatively large mass of fresh tissue required to make the measurements. It is hoped that, in the near future, sensitive and specific antibodies will permit the characterisation of aromatase expression in breast carcinomas using immunohistochemical techniques. This will allow the relationship between aromatase and the clinical benefit derived from aromatase inhibitors to be established more conclusively. 


\section{Application of Aromatase Inhibitors in Breast Cancer}

Most data on the effectiveness of aromatase inhibitors in breast cancer are from studies of locally advanced or metastatic disease. Comparative clinical trials have established that the third-generation compounds letrozole and vorozole are more effective than aminoglutethimide and that letrozole is more effective than fadrozole (Bergh et al., 1997; Gershanovich et al., 1998; Tominaga et al., 1998). These data are important because they establish that drugs that achieve essentially complete inhibition of aromatase are more efficacious than those that suppress aromatase by approximately $90 \%$. Thus, over this range of suppression, a clinical response:dose relationship with aromatase inhibition seems to exist.

All of the aromatase inhibitors have shown some benefit over megestrol acetate, the previously standard second-line agent for advanced breast cancer treatment (Buzdar et al., 1996; Dombernowsky et al., 1998; Kaufmann et al., 2000). Aromatase inhibitors have supplanted this agent as the second-line agent of choice.

The most important clinical data, some of the most important in the hormonal treatment of breast cancer for the last decade, have matured over the last couple of years. For over 20 years, tamoxifen was the most widely used agent in breast cancer treatment because of its efficacy and excellent tolerability. Comparative studies of tamoxifen with aminoglutethimide and the secondgeneration inhibitors, 4-hydroxyandrostenedione and fadrozole, showed no improvement in efficacy of these inhibitors over tamoxifen (Perez Carrion et al., 1994; Thurlimann et al., 1996) in advanced beast cancer. However, large clinical trials of tamoxifen versus the third-generation nonsteroidal aromatase inhibitors, anastrozole and letrozole, have reported greater efficacy of the aromatase inhibitors over the antiestrogen (Nabholtz et al., 1999; Bonneterre et al., 2000; Mouridsen et al., 2001). Thus, in patients with estrogen receptor- and/or progesterone receptor-positive advanced breast cancer, an aromatase inhibitor will now be the first agent of choice.

\section{Neoadjuvant Therapy}

The conventional approach to the management of operable breast cancer is the immediate removal of the primary lesion and the subsequent delivery of adjuvant medical treatment. Neoadjuvant therapy reverses this process such that medical treatment is given prior to surgery. A series of small studies suggested that aromatase inhibitors might be more effective than tamoxifen in this context (Dixon et al., 1999), although this was not confirmed in a relatively small study of vorozole versus tamoxifen (Harper-Wynne et al., 2001). Most importantly, however, a large, double-blind, randomized study has confirmed that letrozole is a substantially more effective agent in primary breast cancer therapy than is tamoxifen, thus confirming the enhanced effectiveness of this compound in 
advanced disease (Ellis et al., 2001). Neoadjuvant studies have the advantage of allowing correlation between the presence of specific biomarkers in the disease before treatment and the clinical response in the same lesion immediately afterwards. Particularly provocative data (Ellis et al., 2001) indicate that letrozole is more effective in steroid-receptor positive tumours, which are also either epidermal growth factor (EGF) receptor or HER-2 positive, than in those that are growth factor receptor negative (Figure 4). While this observation concurs with some preclinical studies (Kurokawa et al., 2000), further clinical evidence is required to confirm these potentially highly important data.

\section{Adjuvant Therapy}

Survival benefit rarely is shown in comparative advanced breast cancer studies. Medical agents generally need to be applied immediately after surgery as adjuvant therapy to achieve marked improvements in survival. It is well established that in estrogen receptor-positive disease, tamoxifen reduces the odds of death by about $30 \%$ after 5 years of use (Early Breast Cancer Trialists'

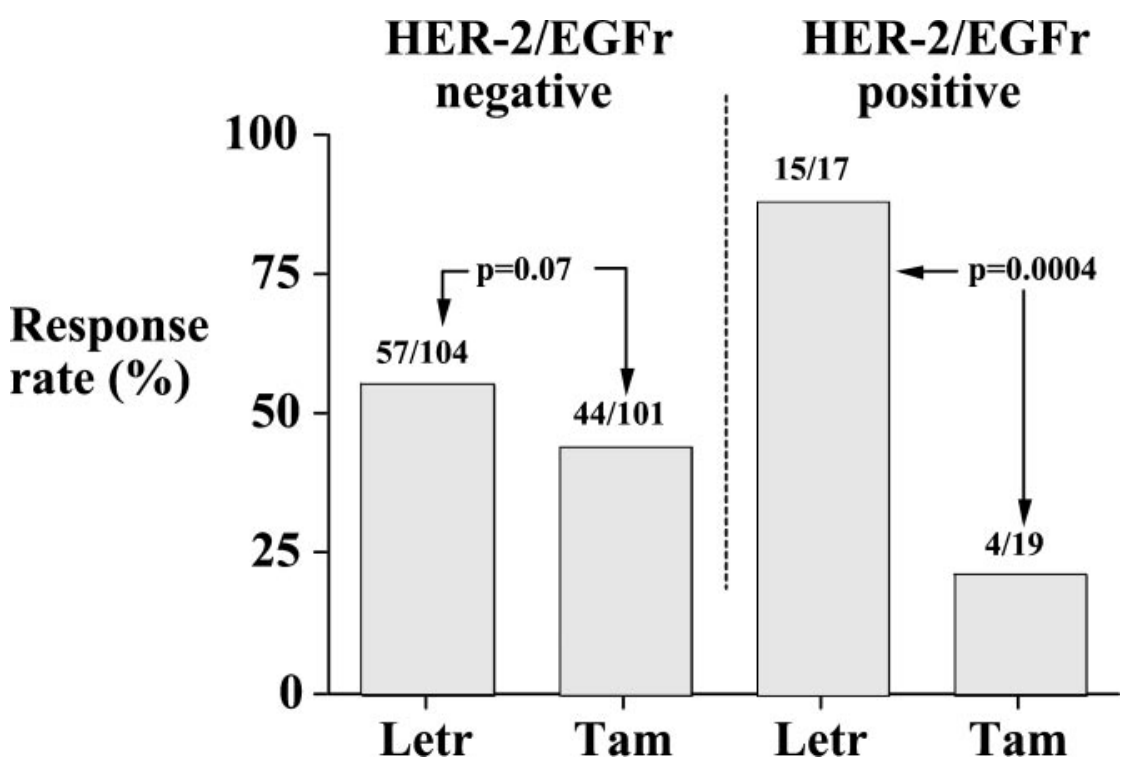

FIG. 4. Response rates to letrozole and tamoxifen according to HER2/EGFr studies in a neoadjuvant clinical trial in primary breast cancer. All patients were either EDR or PgR positive. [Data from Ellis MJ, Coop A, Singh B, Mauriac L, Llombert-Cussac A, Janicke F, Miller WR, Evans DB, Dugan M, Brady C, Quebe-Fehling E, Borgs M 2001 Letrozole is more effective neoadjuvant endocrine therapy than tamoxifen for ErbB-1- and/or ErbB-2-positive, estrogen receptor-positive primary breast cancer: evidence from a phase III randomized trial. J Clin Oncol 19:3808-3816.] 
Collaborative Group, 1998). The very encouraging data from comparisons between tamoxifen and aromatase inhibitors in advanced breast cancer and neoadjuvant therapy prompt the hope that the inhibitors can improve upon the survival seen with tamoxifen in adjuvant therapy. Thus, several very large comparative trials of aromatase inhibitors versus tamoxifen and others will assess the application of these agents in sequence in patients with no apparent metastatic disease. It is important to note that long-term side effects may be as important as efficacy data in this population of patients. It is clear that estrogen deprivation might have adverse effects on the integrity of bone in postmenopausal women (Harper-Wynne et al., 2001). Possible effects on cardiovascular and cognitive function could adversely influence the applicability of inhibitors in this context. Thus, each of the ongoing, large studies is systematically collecting detailed information on these issues of tolerability.

\section{Prospects for Preventative Use}

The involvement of estrogens as promoters of breast cancer is very well established, being based on a wealth of indirect epidemiological evidence (Henderson, 1989). For example, early menarche and late menopause, which extend the exposure of the breast to cyclical estrogenic stimuli, both increase risk of breast cancer. Obesity in postmenopausal women, which increases the plasma concentrations of estrogens, and the application of hormone replacement therapy also enhance breast cancer risk. Of particular note is a series of prospective studies that have collected plasma from women many years before they developed breast cancer. This study has consistently indicated that increased plasma levels of estrogen are associated with increased breast cancer incidence (Thomas et al., 1997). These observations have encouraged the experimental application of agents that can attenuate the estrogenic stimulation of the breast as agents for the prophylaxis of breast cancer. The observations that tamoxifen can reduce the incidence of breast cancer in women at increased risk by approximately $50 \%$ over a 4-year period (Fisher et al., 1998; Cauley et al., 2001) and that the selective estrogen receptor modulator (SERM) raloxifene reduces the incidence of breast cancer in women at high osteoporotic risk have both provided support to this concept and have led aromatase inhibitors being considered as potential preventative agents. The observation that fadrozole can markedly reduce the incidence of sporadic mammary tumours in Sprague-Dawley rats over their lifetime (Gunson et al., 1995) provides compelling support for this concept.

If the effects of tamoxifen and raloxifene are dependent on their antagonising estrogen signalling, the aromatase inhibitors would be expected to be at least as effective in preventing breast cancer. An additional advantage of the inhibitors over the SERMs is that the aromatase inhibitors would be expected to reduce development of genotoxic DNA adducts that may result from the chemical 
reactivity of catecholestrogen metabolites and have a theoretical basis for being involved with breast cancer development (Cavalieri et al., 1997). However, in the chemopreventive setting, side effects are of particular importance, especially in women at only moderate risk. SERMs such as tamoxifen and raloxifene may have an advantage over aromatase inhibitors in this regard. The former have been found to reduce the incidence of osteoporotic fractures (Fisher et al., 1998; Ettinger et al., 1999) and to have effects on lipids that might be expected to have a beneficial effect on cardiac disease (Powles et al., 1989; Johnston et al., 2000). In contrast, the SERMs have deleterious effects on incidence of thrombo-embolic events and tamoxifen enhances the incidence of endometrial cancer (Fisher et al., 1998). Any studies of aromatase inhibitors in the chemopreventative setting will need to consider these issues and compare the effectiveness and side effects of aromatase inhibitors with those of tamoxifen.

One approach to reducing the possible impact of aromatase inhibitors on normal tissues would be to target the therapy at those women with the highest exposure to endogenous estrogens. These could, for example, be identified by plasma estrogen measurements or, alternatively, by assessment of bone mineral density (BMD). BMD tends to reflect long-term estrogen exposure and is itself linked to breast cancer incidence. Rather than obliterating the residual estrogen in these postmenopausal women, a partial reduction in estrogen levels to those in women with low risk of breast cancer is an attractive concept. However, this may be difficult to achieve with low-dose aromatase inhibitors because of variable intersubject pharmacokinetics and pharmacodynamics.

\section{Selective Aromatase Modulators}

Another approach to reducing the risk of side effects is to develop tissuespecific inhibitors of aromatase expression, rather than inhibitors of the catalytic activity. Third-generation aromatase inhibitors are finding utility in the treatment of estrogen-dependent diseases such as breast cancer and, more recently, endometriosis (Zeitoun et al., 1999). However, a disadvantage is that they inhibit aromatase activity in a global fashion and thus could adversely impact sites where estrogen is required for normal function (e.g., maintenance of bone mineralization, prevention of hepatic steatosis and loss of cognitive function). The concept of selective aromatase modulators (SAMs) is made possible by three considerations. The first is that, in postmenopausal women and in men, estrogen largely acts at a local level in sites where it is produced in a paracrine or even intracrine fashion. Second, aromatase expression in these different tissue sites of expression is regulated by tissue-specific promoters. Third, various tissuespecific aromatase promoters employ different signalling pathways and thus different cohorts of transcription factors. Therefore, it is possible to envision 
tissue-specific inhibition of aromatase expression in a similar fashion to the concept of tissue-specific regulation of estrogen action (the concept of SERMs).

As indicated previously, when a breast tumour is present, aromatase activity within the tumour and its surrounding adipose tissue is such that intratumoural estradiol levels are at least an order of magnitude greater than those in circulating plasma of postmenopausal women. (This may be one reason why HRT carries relatively little increased risk of breast cancer.) This is because the tumour produces factors that stimulate aromatase expression locally. This stimulation is associated with switching of the aromatase gene promoter from I.4 to promoter II, the gonadal-type promoter (Harada et al., 1993; Agarwal et al., 1996; Zhou et al., 1997) (Figure 5). Thus, drugs that target promoter II-driven expression of aromatase would be most useful. In postmenopausal women, this promoter would appear to be exclusively utilized in tumour-containing breast tissue (and

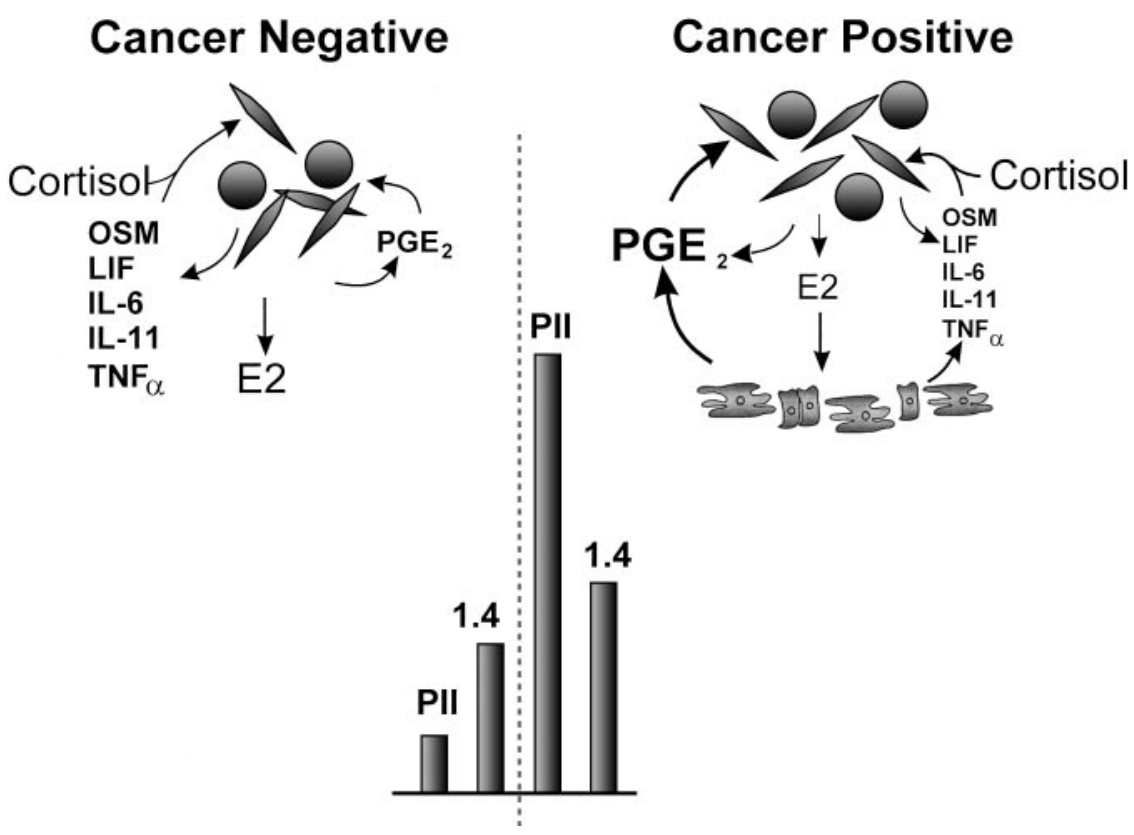

FIG. 5. Proposed regulation of aromatase gene expression in breast adipose tissue from cancer-free individuals and from those with breast cancer. In the former case, expression is stimulated primarily by class I cytokines and tumour necrosis factor alpha produced locally, in the presence of systemic glucocorticoids. As a consequence, promoter I.4-specific transcripts of aromatase predominate. In the latter case, aromatase expression is increased and promoter II-specific transcripts of aromatase predominate, suggesting a major role for prostaglandin E2 $\left(\mathrm{PGE}_{2}\right)$ in aromatase expression. $\mathrm{PGE}_{2}$ in this case could be derived from the tumourous epithelium, tumour-derived fibroblasts, and/or macrophages recruited to the tumour site. 
in endometriotic plaques) (Agarwal et al., 1996; Zeitoun et al., 1999). Thus, bone in particular, which does not express promoter-II specific transcripts (Shozu and Simpson, 1998), would be spared.

Tumour-derived factors include prostaglandin E (PGE) $)_{2}$ (Schrey and Patel, 1995), which stimulates adenylate cyclase in adipose stromal cells, and promoter II, which is regulated by cAMP. It was found that $\mathrm{PGE}_{2}$ is a powerful stimulator of aromatase expression in these cells via promoter II (Zhao et al., 1996). Moreover, expression of the CYP19 gene was correlated with COX-1 and COX-2 expression in human breast cancer and normal tissue specimens (Brueggemeier et al., 1999). A case-control study published some years ago indicated that daily use of nonsteroidal, anti-inflammatory drugs such as ibuprofen reduced the incidence of breast tumours by up to $40 \%$ (Harris et al., 1996). More recently, it has been shown that the COX-2 inhibitor, celecoxib, has strong chemopreventive activity against mammary carcinoma in rats (Harris et al., 2000). From these considerations, it appears likely that inhibition of aromatase expression selectively in breast tissue could play an important role in this chemopreventive action of cyclo-oxygenase inhibitors, which therefore might qualify as the first generation of SAMs. However, ongoing research on regulation of aromatase expression in the breast is likely to uncover other candidates in the not-too-distant future.

\section{ACKNOWLEDGMENTS}

The authors gratefully acknowledge the work of their colleagues and collaborators, in particular, Colin Clyne, Serdar Bulun, Susan Davis, Per Lonning, Ian Smith, and Steve Johnston. The work from the Simpson lab was supported by a grant from the Victorian Breast Cancer Research Consortium Inc. and by U.S. Public Health Service Grant \#R37 AG08174. Sue Elger provided skilled editorial assistance.

\section{REFERENCES}

Agarwal VR, Bulun SE, Leitch M, Rohrich R, Simpson ER 1996 Use of alternative promoters to express the aromatase cytochrome P450 (CYP19) gene in breast adipose tissues of cancer-free and breast cancer patients. J Clin Endocrinol Metab 81:3843-3849

Bajetta E, Zilembo N, Dowsett M, Guillevin L, Di Leo A, Celio L, Martinetti A, Marchiano A, Pozzi P, Stani S, Bichisao E 1999 Double-blind, randomised, multicentre endocrine trial comparing two letrozole doses, in postmenopausal breast cancer patients. Eur J Cancer 35:208-213

Bergh J, Bonneterre J, Illiger HJ, Murray R, Nortier J, Paridaens R, Rubens RD, Samonigg H, van Zyl J, for the Vorozole Study Group 1997 Vorozole versus aminoglutethimide in the treatment of postmenopausal breast cancer relapsing after tamoxifen. Proc Am Soc Clin Oncol $16: 1551$

Bhatnagar AS, Brodie AM, Long BJ, Evans DB, Miller WR 2001 Intracellular aromatase and its relevance to the pharmacological efficacy of aromatase inhibitors. J Steroid Biochem Mol Biol 76:199-202 
Boeddinghaus I, Dowsett, M 2002 Comparative clinical pharmacology and pharmacokinetic interactions of aromatase inhibitors. J Steroid Biochem Mol Biol, in press

Bonneterre J, Thurlimann B, Robertson JF, Krzakowski M, Mauriac L, Koralewski P, Vergote I, Webster A, Steinberg M, von Euler M 2000 Anastrozole versus tamoxifen as first-line therapy for advanced breast cancer in 668 postmenopausal women: results of the Tamoxifen or Arimidex Randomized Group Efficacy and Tolerability study. J Clin Oncol 18:3748-3757

Brodie AM, Garrett WM, Hendrickson JR, Tsai-Morris CH, Williams JG 1983 1. Estrogen antagonists. Aromatase inhibitors, their pharmacology and application. J Steroid Biochem 19:53-58

Brodie AMH, Garrett WM, Hendrickson JR, Tsai-Morris CH, Marcotte PA, Robinson CH 1981 Inactivation of aromatase in vitro by 4-hydroxy-4androstene-3,17-dione and 4-acetoxy4-androstene-3,17-dione and sustained effects in vivo. Steroids 38:693-702

Brueggemeier RW, Quinn AL, Parrett ML, Joarder FS, Harris RE, Robertson FM 1999 Correlation of aromatase and cyclo-oxygenase gene expression in human breast cancer specimens. Cancer Lett 140:27-35

Buzdar A, Howell A 2001 Advances in aromatase inhibition: clinical efficacy and tolerability in the treatment of breast cancer. Clin Cancer Res 7:2620-2635

Buzdar A, Jonat W, Howell A, Jones SE, Blomqvist C, Vogel CL, Eiermann W, Wolter JM, Azab M, Webster A, Plourde PV 1996 Anastrozole, a potent and selective aromatase inhibitor, versus megestrol acetate in postmenopausal women with advanced breast cancer: results of overview analysis of two phase III trials. Arimidex Study Group. J Clin Oncol 14:2000-2011

Cauley JA, Norton L, Lippman ME, Eckert S, Krueger KA, Purdie DW, Farrerons J, Karasik A, Mellstrom D, Ng KW, Stepan JJ, Powles TJ, Morrow M, Costa A, Silfen SL, Walls EL, Schmitt H, Muchmore DB, Jordan VC 2001 Continued breast cancer risk reduction in postmenopausal women treated with raloxifene: 4-year results from the MORE trial. Multiple outcomes of raloxifene evaluation. Breast Cancer Res Treat 65:125-134

Cavalieri EL, Stack DE, Devanesan PD, Todorovic R, Dwivedy I, Higginbotham S, Johansson SL, Patil KD, Gross ML, Gooden JK, Ramanathan R, Cerny RL, Rogan EG 1997 Molecular origin of cancer: catechol estrogen-3,4-quinone as endogenous tumor initiators. Proc Natl Acad Sci USA 94:10937-10942

De Coster R, Van Ginckel RF, Callens MJ, Goeminne NK, Janssens BL 1992 Antitumoral and endocrine effects of $(+)$-vorozole in rats bearing dimethylbenzanthracene-induced mammary tumors. Cancer Res 52:1240-1244

DeJong PC, ven de Ven J, Nortier HW, Maitimu-Sneede I, Danker TH, Thijssen JH, Slee PH, Blankenstein RA 1997 Inhibition of breast cancer tissue aromatase activity and estrogen concentrations by the third-generation aromatase inhibitor vorozole. Cancer Res 57:21092111

Dixon JM, Love CD, Renshaw L, Bellamy C, Cameron DA, Miller WR, Leonard RC 1999 Lessons from the use of aromatase inhibitors in the neoadjuvant setting. Endocr Relat Cancer 6:227-230

Dombernowsky P, Smith I, Falkson G, Leonard R, Panasci L, Bellmunt J, Bezwoda W, Gardin G, Gudgeon A, Morgan M, Fornasiero A, Hoffmann W, Michel J, Hatschek T, Tjabbes T, Chaudri HA, Hornberger U, Trunet PF 1998 Letrozole, a new oral aromatase inhibitor for advanced breast cancer: double-blind randomized trial showing a dose effect and improved efficacy and tolerability compared with megestrol acetate. J Clin Oncol 16:453-461

Dowsett M, Goss PE, Powles TJ, Hutchinson G, Brodie AM, Jeffcoate SL, Coombes RC 1987 Use of the aromatase inhibitor 4-hydroxyandrostenedione in postmenopausal breast cancer: optimization of therapeutic dose and route. Cancer Res 47:1957-1961 
Early Breast Cancer Trialists' Collaborative Group 1998 Tamoxifen for early breast cancer: an overview of the randomised trials. Lancet 351:1451-1467

Ellis MJ, Coop A, Singh B, Mauriac L, Llombert-Cussac A, Janicke F, Miller WR, Evans DB, Dugan M, Brady C, Quebe-Fehling E, Borgs M 2001 Letrozole is more effective neoadjuvant endocrine therapy than tamoxifen for ErbB-1- and/or ErbB-2-positive, estrogen receptor-positive primary breast cancer: evidence from a phase III randomized trial. J Clin Oncol 19:3808-3816

Ettinger B, Black DM, Mitlak BH, Knickerbocker RK, Nickelsen T, Genant HK, Christiansen C, Delmas PD, Zanchetta JR, Stakkestad J, Gluer CC, Krueger K, Cohen FJ, Eckert S, Ensrud KE, Avioli LV, Lips P, Cummings SR 1999 Reduction of vertebral fracture risk in postmenopausal women with osteoporosis treated with raloxifene: results from a 3-year randomized clinical trial. Multiple Outcome of Raloxifene Evaluation (MORE) Investigators. JAMA 282:637-645

Fisher B, Costantino JP, Wickerham DL, Redmond CK, Kavanah M, Cronin WM, Vogel V, Robidoux A, Dimitrov N, Atkins J, Daly M, Wieand S, Tan-Chiu E, Ford L, Wolmark N 1998 Tamoxifen for prevention of breasst cancer: report of the National Surgical Adjuvant Breast and Bowel Project P-1 Study. J Natl Cancer Inst 90:1371-1388

Geisler J, King N, Anker G, Ornati G, Di Salls E, Lonning PE, Dowsett M 1998 In vivo inhibition of aromatization by exemestane, a novel irreversible aromatase inhibitor, in postmenopausal breast cancer patients. Clin Cancer Res 4:2089-2093

Geisler J, Haynes B, Anker G, Dowsett M, Lonning PE 2002 Influence of letrozole and anastrozole on total body aromatization and plasma estrogen levels in postmenopausal breast cancer patients evaluated in a randomized cross-over-designed study. J Clin Oncol, in press

Gershanovich M, Chaudri HA, Campos D, Lurie H, Bonaventura A, Jeffrey M, Buzzi F, Bodrogi I, Ludwig H, Reichardt P, O'Higgins N, Romieu G, Friederich P, Lassus M 1998 Letrozole, a new oral aromatase inhibitor: randomised trial comparing $2.5 \mathrm{mg}$ daily, 0.5 $\mathrm{mg}$ daily and aminoglutehimide in postmenopausal women with advanced breast cancer. Letrozole International Trial Group (AR/BC3). Ann Oncol 9:639-645

Goss PE, Strasser K 2001 Aromatase inhibitors. J Clin Oncol 19:881-894

Graham-Lorence S, Amarneh B, White RE, Peterson JA, Simpson ER 1995 A three-dimensional model of aromatase cytochrome P450. Protein Sci 4:1065-1080

Graham-Lorence S, Peterson JA 1996 P450s: structural similarities and functional differences. FASEB J 10:206-214

Gunson DE, Steele RE, Chau RY 1995 Prevention of spontaneous tumours in female rats by fadrozole hydrochloride, an aromatase inhibitor. Br J Cancer 72:72-75

Harada N, Utsume T, Takagi Y 1993 Tissue-specific expression of the human aromatase cytochrome P450 gene by alternative use of multiple exons 1 and promoters, and switching of tissue-specific exons 1 in carcinogenesis. Proc Natl Acad Sci USA 90:11312-11316

Harada N, Yamada K, Saito K, Kibe N, Dohmae S, Takagi Y 1990 Structural characterization of the human estrogen synthetase (aromatase gene). Biochem Biophys Res Commun 166: $365-372$

Harper-Wynne C, Sacks NP, Shenton K, MacNeill FA, Sauven P, Laidlaw IJ, Rayter Z, Miall S, Salter J, Hills MJ, Lowe FM, A’Hern RA, Nasiri N, Doody D, Iqbal J, Dowsett M 2002 Comparison of the systemic and intratumoural effects of tamoxifen and the aromatase inhibitor vorozole in postmenopausal patients with breast cancer. J Clin Oncol, in press

Harris RE, Alshafie GA, Abou-Issa H, Seibert K 2000 Chemoprevention of breast cancer in rats by celecoxib, a cycloxygenase 2 inhibitor. Cancer Res 60:2101-2113

Harris RE, Namboodiri KK, Farrar WB 1996 Non-steroidal anti-inflammatory drugs and breast cancer. Epidemiology 7:203-205 
Henderson BE 1989 Endogenous and exogenous endocrine factors. Hematol Oncol Clin N Am 3:577-598

Jacobs S, Lonning PE, Haynes B, Griggs L, Dowsett M 1991 Measurement of aromatisation by a urine technique suitable for the evaluation of aromatase inhibitors in vivo. J Enzyme Inhib 4:4315-4325

Johnston CC Jr, Bjarnason NH, Cohen FJ, Shah A, Lindsay R, Mitlak BH, Huster W, Draper MW, Harper KD, Heath H III, Gennari C, Christiansen C, Arnaud CD, Delmas PD 2000 Long-term effects of raloxifene on bone mineral density, bone turnover, and serum lipid levels in early postmenopausal women: three-year data from 2 double-blind, randomized, placebocontrolled trials. Arch Intern Med 160:3444-3450

Jones AL, MacNeill F, Jacobs S, Lonning PE, Dowsett M, Powles TJ 1992 The influence of intramuscular 4-hydroxyandrostenedione on peripheral aromatisation in breast cancer patients. Eur J Cancer 28A:1712-1716

Kao YC, Cam LL, Laughton CA, Zhou D, Chen S 1996 Binding characteristics of seven inhibitors of human aromatase: a site-directed mutagenesis study. Cancer Res 56:3451-3460

Kaufmann M, Bajetta E, Dirix LY, Fein LE, Jones SE, Zilembo N, Dugardyn JL, Nasurdi C, Mennel RG, Cervek J, Fowst C, Polli A, di Salle E, Arkhipov A, Piscitelli G, Miller LL, Massimini G 2000 Exemestane is superior to megestrol acetate after tamoxifen failure in postmenopausal women with advanced breast cancer: results of a phase III randomized double-blind trial. The Exemestane Study Group. J Clin Oncol 18:1399-1411

Kurokawa H, Lenferink AE, Simpson JF, Pisacane PI, Sliwkowski MX, Forbes JT, Arteaga CL 2000 Inhibition of HER2/neu (erbB-2) and mitogen-activated protein kinases enhances tamoxifen action against HER2-overexpressing, tamoxifen-resistant breast cancer cells. Cancer Res 60:5887-5894

Labrie F, Belanger A, Cusan L, Candas B 1997a Physiological changes in dehydroepiandrosterone are not reflected by serum levels of active androgens and estrogen but of their metabolites: intracrinology. J Clin Endocrinol Metab 82:2403-2409

Labrie F, Belanger A, Cusan L, Gomez JL, Candas B 1997b Marked decline in serum concentrations of adrenal C19 sex steroid precursor. J Clin Endocrinol Metab 82: 2396-2402

Labrie F, Belanger A, Luu-The V, Labrie C, Simond J, Cusan L, Gomez JL, Candas B 1998 DHEA and the intracrine formation of androgens and estrogens in peripheral target tissues: its role during aging. Steroids 63:322-328

Lee K, Macaulay VM, Nicholls JE, Detre S, Ashworth A, Dowsett M 1995 An in vivo model of intratumoural aromatase using aromatase-transfected MCF7 human breast cancer cells. Intl J Cancer 62:297-302

Lonning PE 2000 Clinico-pharmacological aspects of different hormone treatments. Eur J Cancer 36:S81-S82

Lonning PE, Jacobs S, Jones A, Haynes B, Powles T, Dowsett M 1991 The influence of CGS 16949A on peripheral aromatisation in breast cancer patients. Br J Cancer 63:789-793

Lu Q, Yue W, Wang J, Liu Y, Long B, Brodie A 1998 The effects of aromatase inhibitors and antiestrogens in the nude mouse model. Breast Cancer Res Treat 50:63-71

MacNeill FA, Jones AL, Jacobs S, Lonning PE, Powles TJ, Dowsett M 1992 The influence of aminoglutethimide and its analogue rogletimide on peripheral aromatisation in breast cancer. Br J Cancer 66:692-697

Mahendroo, MS, Mendelson, CR, Simpson ER 1993 Tissue-specific and hormonally controlled alternative promoters regulate aromatase cytochrome $\mathrm{P} 450$ gene expression in human adipose tissue. J Biol Chem 268:19463-19470

Means GD, Kilgore MW, Mahendroo MS, Mendelson CR, Simpson ER 1991 Tissue-specific promoters regulate aromatase cytochrome P450 gene expression in human ovary and fetal tissues. Mol Endocrinol 5:2005-2013 
Means GD, Mahendroo M, Corbin CJ, Mathis JM, Powell FE, Mendelson CR, Simpson ER 1989 Structural analysis of the gene encoding human aromatase cytochrome P-450, the enzyme responsible for estrogen biosynthesis. J Biol Chem 264:19385-19391

Miller WR 1999 Biology of aromatase inhibitors: pharmacology/endocrinology within the breast. Endocr Relat Cancer 6:187-195

Miller WR, O'Neill J 1987 The importance of local synthesis of estrogen within the breast. Steroids 50:537-548

Mitwally MF, Casper RF 2001 Use of an aromatase inhibitor for induction of ovulation in patients with an inadequate response to clomiphene citrate. Fertil Steril 75:305-309

Mouridsen H, Gershanovich M, Sun Y, Perez-Carrion R, Boni C, Monnier A, Apffelstaedt J, Smith R, Sleeboom HP, Janicke F, Pluzanska A, Dank M, Becquart D, Bapsy PP, Salminen E, Snyder R, Lassus M, Verbeek JA, Staffler B, Chaudri-Ross HA, Dugan M 2001 Superior efficacy of letrozole versus tamoxifen as first-line therapy for postmenopausal women with advanced breast cancer: results of a phase III study of the International Letrozole Breast Cancer Group. J Clin Oncol 19:2596-2606

Nabholtz JM, Buzdar A, Pollak M, Harwin W, Burton G, Mangalik A, Steinberg M, Webster A, von Euler M 2000 Anastrozole is superior to tamoxifen as first-line therapy for advanced breast cancer in postmenopausal women: results of a North American multicenter randomized trial. Arimidex Study Group. J Clin Oncol 18:3758-3767

Nelson DR, Koymans L, Kamataki T, Stegeman JJ, Feyereisen R, Waxman DJ, Waterman MR, Gotoh O, Coon MJ, Estabrook RW, Gunsalus IC, Nebert DW 1996 P450 superfamily: update on new sequences, gene mapping, accession numbers and nomenclature. Pharmacogenetics $6: 1-42$

Pasqualini JR, Chetrite G, Blacker C, Feinstein MC, Delalonde L, Talbi M, Maloche C 1996 Concentrations of estrone, estradiol, and estrone sulfate and evaluation of sulfatase and aromatase activities in pre and postmenopausal breast cancer patients. J Clin Endocrinol Metab 81:1460-1464

Perez Carrion R, Alberola Candel V, Calabresi F, Michel RT, Santos R, Delozier T, Goss P, Mauriac L, Feuilhade F, Freue M 1994 Comparison of the selective aromatase inhibitor formestane with tamoxifen as first-line hormonal therapy in postmenopausal women with advanced breast cancer. Ann Oncol 7:S19-S24

Powles TJ, Hardy JR, Ashley SE, Farrington GM, Cosgrove D, Davey JB, Dowsett M, McKinna JA, Nash AG, Sinnett HD, Tillyer CR, Treleaven JG 1989 A pilot trial to evaluate the acute toxicity and feasibility of tamoxifen for prevention of breast cancer. Br J Cancer 60:126-131

Reed MJ, Owen AM, Lai LC, Coldham NG, Ghilchik MW, Shaikh NA, James VH 1989 In situ oestrone synthesis in normal breast and breast tumour tissues: effect of treatment with 4-hydroxyandrostenedione. Intl J Cancer 44:233-237

Santen RJ, Santner S, Davis R, Veldhuis J, Samojlik E, Ruby E 1978 Aminoglutehimide inhibits extraglandular estrogen production in postmenopausal women with breast carcinoma. J Clin Endocrinol Metab 47:1257-1265

Sasano H, Uzuki M, Sawai T, Nagura H, Matsunaga G, Kashimoto O, Harada N 1997 Aromatase in human bone tissue. J Bone Miner Res 12:1416-1423

Schrey MP, Patel KV 1995 Prostaglandin E2 production and metabolism in human breast cancer cells and breast fibroblasts. Regulation by inflammatory mediators. Br J Cancer 72:1412-1419

Sebastian S, Bulun SE 2001 A highly complex organization of the regulatory region of the human CYP19 (aromatase) gene revealed by the human genome project. J Clin Endocrinol Metab $86: 4600-4602$

Shetty G, Krishnamurthy H, Krishnamurthy HN, Bhatnagar AS, Mondgal RN 1997 Effect of estrogen deprivation on the reproductive physiology of male and female primates. J Steroid Biochem Mol Biol 61:157-166 
Shozu M, Simpson ER 1998 Aromatase expression of human osteoblast-like cells. Mol Cell Endocrinol 139:117-129

Simpson ER, Rubin G, Clyne C, Robertson K, O'Donnell L, Jones M, Davis S 2000 The role of local estrogen biosynthesis in males and females. Trends Endocrinol 5:184-188

Simpson ER, Zhao Y, Agarwal VR, Michael, MD, Bulun SE, Hinshelwood MM, GrahamLorence S, Sun T, Fisher CR, Qin K, Mendelson CR 1997 Aromatase expression in health and disease. Rec Progr Horm Res 52:185-214

Stuart-Harris R, Dowsett M, Bozek T, McKinna JA, Gazet JC, Jeffcoate SL, Kurkure A, Carr L, Smith IE 1984 Low-dose aminoglutehimide in treatment of advanced breast cancer. Lancet 2:604-607

Thomas HV, Reeves GK, Key TJ 1997 Endogenous estrogen and postmenopausal breast cancer: quantitative review. Cancer Causes Control 8:922-928

Thompson EA Jr, Siiteri PK 1974 Utilization of oxygen and reduced nicotinamide adeninedinucleotide phosphate by human placental microsomes during aromatization of androstenedione. J Biol Chem 249:5364-5372

Thurlimann B, Beretta K, Bacchi M, Castiglione-Gertsch M, Goldhirsch A, Jungi WF, Cavalli F, Senn HJ, Fey M, Lohnert T 1996 First-line fadrozole HCI (CGS 16949A) versus tamoxifen in postmenopausal women with advanced breast cancer. Prospective randomised trial of the Swiss Group for Clinical Cancer Research SAKK 20/88. Ann Oncol 7:471-479

Toda K, Terashima M, Kamamoto T, Sumimoto H, Yamamoto Y, Sagara Y, Ikeda H, Shizuta Y 1990 Structural and functional characterization of human aromatase. Eur J Biochem 193:559-565

Tominaga T, Morimoto T, Ohasi Y, for the Japan Letrozole Study Group 2000 A pivotal double-blind trial in Japan of an aromatase inhibitor Letrozole (third generation) vs. its predecessor fadrozole hydrochloride (second generation). Ann Oncol 11 (suppl):25

van der Wall E, Donker TH, de Frankrijker E, Nortier HW, Thijssen JH, Blankenstein MA 1993 Inhibition of the in vivo conversion of androstenedione to estrone by the aromatase inhibitor vorozole in healthy postmenopausal women. Cancer Res 53:4563-4566

Zeitoun K, Takayama K, Michael MD, Bulun SE 1999 Stimulation of aromatase P450 promoter (II) activity in endometriosis and its inhibition in endometrium are regulated by competitive binding of steroidogenic factor-1 and chicken ovalbumin upstream promoter transcription factor to the same cis-acting element. Mol Endocrinol 13:239-253

Zhao Y, Agarwal VR, Mendelson CR, Simpson ER 1996 Estrogen biosynthesis proximal to a breast tumor is stimulated by PGE2 via cyclic AMP, leading to activation of promoter II of the CYP19 (aromatase) gene. Endocrinology 137:5739-5742

Zhou J, Zhou C, Chen S 1997 Gene regulation studies of aromatase expression in breast cancer and adipose stromal cells. J Steroid Biochem Mol Biol 61:273-280 